International Journal of Social Science and Economic Research

ISSN: 2455-8834

Volume:06, Issue:06 "June 2021"

\title{
THE PROHIBITION OF CHILD MARRIAGE ACT, 2006
}

\author{
Kalyani Roy \\ School of Law, Bennett University, Greater Noida
}

DOI: 10.46609/IJSSER.2021.v06i06.009 URL: https://doi.org/10.46609/IJSSER.2021.v06i06.009

\section{INTRODUCTION}

The existence of child marriage even after 70 years of independence is an evil truth and a gruesome reality that many girl children are victims to. Even after the presence of various laws, we still find the rampant child marriage practices that are being still carried on in various parts of India, especially the rural areas.

The reasons given or analyzed of the continuance of these practices are many. The theory of demand- supply in economics state that the supply of a good or service is not possible until there is a demand for it. Hence, we can state that one of the main factors that still exists for such practices is the demand of young brides, poverty, dowry etc. which will be dealt later in the paper.

The practices of child marriage, is not something that has been discovered in recent times, but such socio-evil practices dates back to centuries and is one of the main examples of how women have been subjected to continuous discrimination and have been objectified and have been denied various rights which a human deserves, such as a right to live freely, to have the freedomto express and speak for themselves, to take a stand for themselves and to have the power to take decisions.

Various committees have been constituted to look closely in the matter and to analyze the existence and the increasing number of child marriages even after the presence of various laws. This is something that clearly indicates that the laws that have been drafted as well as the implementation of these laws have failed, which means that still there are many aspects that have been ignored or that haven't been addressed. Some of these reasons can be the patriarchalmindset that of the legislature which has failed to see or understand the actual trauma or the needs to the woman. One of the other factors that has also led to the formulation of such ineffective laws is because, they have been framed in an environment of exclusion. What this means is that the laws have been framed in a way which excludes the particular needs, rights, voices and experiences of the people who could have acknowledged and addressed these factors better, that are women 
International Journal of Social Science and Economic Research

ISSN: 2455-8834

Volume:06, Issue:06 "June 2021"

themselves.

The enactment of the CHILD MARRIAGE RESTRAIN ACT,1929 which was a result of the social movement lead by women's group of India was the first and one of the important steps taken to recognize the rights the children and to prevent child marriages. Although the act was passed by the British government, and was also not too effective yet it was first to address and take action against the elephant in room, that was the Child Marriages.

\section{Evolution of laws relating to the child marriages and critical analyses of the present laws}

\section{The Child Restrain Act, 1929}

To prevent the Child marriages practiced in various parts of India as a tradition depriving these young girls from proper educational, personal and social development, the first step taken to encounter this was the enactment of the Child Restrain Act (hereinafter CRA), 1929, and was also known as the "Sarda Act".

At the time of its enactment the word child had been defined as a girl below 14 years of age and a boy below 18 years of age. Some other features of the act were that it made the child marriage a non-cognizable offence and laid down certain light punishment for the same. It allowed the police to commence an investigation after a report was registered. It allowed the police to arrest a person but, only after obtaining an arrest warrant from the Magistrate. The actof 1929 also upheld the validity of a child marriage once the marriage was solemnized, that is a child marriage was considered as absolutely valid. One of the other provisions of the CRA, 1929 was that it allowed to take up the cognizance of a child marriage up to one year and thus after a year the child marriage would not be seen as an offence. It also did not make the registration of the marriage compulsory. ${ }^{1}$

Although the CRA, 1929 was a positive step taken by the legislature to prevent the socio-evil practice of child marriage, yet they could not completely address the problem as there were various lacunas that existed as the law made was not very efficient.

One of the serious problems that could be seen was the discrimination and the difference that was kept in the ages of the girls and the boys. The girls were clearly placed at a disadvantageous position and the article guaranteeing equality for all clearly seemed to have been violated. There was simply no rationale that could have existed for keeping the ages different, and the

1 The Prohibition of Child Marriage Act, 2006: A Critical Analyses, https://shodhganga.inflibnet.ac.in/ lastaccessed on 6 April, 2020. 


\section{International Journal of Social Science and Economic Research}

ISSN: $2455-8834$

Volume:06, Issue:06 "June 2021"

presumption for different mental, physical intellectual etc. development was debatable. Also, it clearly showed the patriarchal mindset of not expecting girls to be educated and to earn and also of always having bride younger than the groom.

Secondly the act recognizes the marriage as a non-cognizable offence and thus prevented the police from taking up cases Suo-moto. Hence the police were not empowered to arrest the person at once for committing the offence of child marriage and thus had to wait for a report to be launched and then were only allowed to investigate. Also, the procedure for arresting the person for committing the offence of child marriage was quite tedious and time consuming and thus served as an opportunity for the people to commit the offence easily. "Thus, the police were neither empowered to arrest nor to stop the child marriage from being solemnized." Also there was no mention to any minimum punishment for committing the offence, which allowed many people who committed the offence of child marriage to go away freely. ${ }^{3}$

Also, the time limit that was set by the act to take up the cognizance once the marriage was solemnized was just one year, which was too less a time, as the parties contracting to marry were minors and also girls were not supported nor aware of their rights and neither did they had the power to stand up against her family or her husband on whom she had been dependent on. Registration of marriage was not made compulsory, which could have acted as a very powerful and efficient tool to curb the child marriage.

The provisions of the CRA, 1929 of holding a solemnized child marriage as perfectly valid wasin itself contradicting to the provisions of the Hindu Marriage Act, 1955, which states that any marriage in contravention to Section 5(iii) would be held to be void ab-initio. Hence the marriage of the parties below 18 years in case of girl and below 21 years if boy would be held to be voidab initio, but here we could see that the CRA,1929, still upheld the validity of child marriages. One of the reason due to which the judiciary upheld the validity of the same was that it relied upon personal laws rather than the Central legislature, ${ }^{4}$ which could be seen by various judgements- the Patna $\mathrm{HC}^{5}$, the Allahabad $\mathrm{HC}^{6}$, the Orissa $\mathrm{HC}^{7}$ and the Madras $\mathrm{HC}^{8}$ all had similar opinion and thus upheld the validity of child marriage. Only the Andhra Pradesh $\mathrm{HC}^{9}$

${ }^{2}$ Law Commission of India, Report number- 205, Proposal to Amend the Prohibition of child Marriage Act, 2006, February 2008, pg 153.

${ }^{3}$ Supra 1

${ }^{4}$ Ibid, pg 154

${ }^{5}$ Mt. Jalsi Kaur vs. Emperor AIR 1933 Patna 471

${ }^{6}$ Ram Baran vs. Sital Pathak AIR 1939 All 34

${ }^{7}$ Birupakshya Das vs. Kunju Behari AIR 1961 Orissa 104

${ }^{8}$ Sivanandy vs. Bhagavathyamma AIR 1962 Mad 400

${ }^{9}$ Panchireddi Appala Suramma vs. Gadela Ganapatlu AIR 1975 AP 193 
International Journal of Social Science and Economic Research

ISSN: 2455-8834

Volume:06, Issue:06 "June 2021"

departed in its judgement and in its opinion, and thus held to the contrary that these marriages were not valid and hence void ab-initio which was again overturned by the same court and was deemed to be valid. ${ }^{10}$

Hence, we can see there were various lacunas that were present in the 1929 Act, and hence the government were unable to prevent these practices efficiently. Hence to battle with these issues, the Law Commission and other organizations such as the CEDAW made suggestions to the government for amendments, which the government of India agreed. Hence, they revoked the CRA, 1929 and replaced it with a new act, now known as the Prohibition of Child Marriage Act (hereinafter PCMA), 2006. ${ }^{11}$

\section{The Prohibition of Child Marriage Act, 2006}

The constant suggestions and recommendations by the National Commission for Women, the National Human Rights Commission etc. the Central government after the assent of the President, finally passed the PCMA, 2006.

The various recommendations were adopted and were included in the new Act. Some of the key features that the PCMA, 2006 included were-

1. Child marriage has been declared to be cognizable, that is a person can be arrested without a warrant, and also a non-bailable offence, that means no bail will be granted unless the person has been presented before a magistrate.

2. The child marriages were declared to be voidable at the option of the aggrieved party. That means either of the party who was a minor can move to the court for annulling the marriage.

3. The punishments were made more stringent and also prescribed a minimum punishment to those who commit the offence. The punishment has increased to "rigorous imprisonment which may extend to 2 years and a fine which may extend to Rs. 1 lakh or both, for, an adult male who marry a child, for solemnizing a child marriage and alsofor promoting or permitting solemnization of a child marriage." 12

4. It made a provision for the maintenance of the girl after the annulment under Section 4.

\footnotetext{
10 Vankataramana vs. State AIR 1977 AP 193

11 Supra 1

12 The Prohibition of Child Marriage Act, 2006, sections 9, 10, 11.
} 


\section{International Journal of Social Science and Economic Research}

ISSN: $2455-8834$

Volume:06, Issue:06 "June 2021"

Hence if the husband is also minor at that time, then his guardians will maintain the girl until she gets remarried.

5. It also made provisions for the maintenance and custody of the child under Section 5.

6. The PCMA also provided for the legitimacy of children that have been born from the marriage, even after the marriage gets annulled. Therefore, any child that has been bornout of the wedlock will be considered to be legitimate according to Section 6.

7. The District Courts have also been empowered to pass any order which they may deemfit in relation to the maintenance of the girl, her residence or custody of the child.

8. The Courts have also been empowered to grant an interim injunction in an emergency situation to stop a child marriage from being solemnized.

9. In cases where the minor is abducted by force, deceitful means by enticement from their lawful guardians for the purpose of marriage, then such marriage will be considered as void. ${ }^{13}$

10. The State governments have also required to appoint a Child Marriage Prohibition Officer and are also empowered to frame rules for effective and efficientimplementation of the Act, in the respective States. ${ }^{14}$

Hence as we can see the PCMA, 2006 was more liberal in its approach as compared to the CRA, 1929. It also catered to a wider range of issues and was also much better and powerful. Even with this approach, the problem of child marriages could not be solved which was still prevalent in many parts of India, especially the rural areas. This was due to the various lacunasor gaps that existed and where not properly filled by the PCMA, 2006. Hence, there is still needfor amendment in the present Act, which will be dealt in the next question. After critically analyzing the PCMA, 2006, there were various lacunas as highlighted here-

1. No existence of rationale in keeping the minimum age for marriage different for boys and girls. This suggests the patriarchal mindset of the law makers in making this differentiation. It shows that the girls are not expected to take higher studies and thus can marry at an early age rather than boys who are considered the bread winners.

\footnotetext{
${ }^{13}$ Ibid, section 12.

${ }^{14}$ Supra 1
} 


\section{International Journal of Social Science and Economic Research}

ISSN: $2455-8834$

Volume:06, Issue:06 "June 2021"

2. Firstly, provision which allowed the annulment of the child marriage was very weak and secondly, Section 3 which provides time limit to seek an annulment up to 2 years is also very unreasonable. This is because the girls are forced to marry at a very young age and thus neither they have any power in making decisions nor the power to stand for themselves. Hence, we cannot accept these girls who are just 20 years of age or even less whereas the boy would be 23 years, to be aware of their rights, to stand up against everyone and seek annulment. Also, these girls have always been dependent and do not possess the survival techniques, hence the fear of not being able to survive and no support from their family would prevent them from getting the marriage annulled.

3. The PCMA, 2006 although have attached more stringent and increased punishment for committing the offence of child marriage, yet it fails at attaching a minimum punishment to it, hence most offenders go freely. "in the year 2011, there were 113 cases registered out of which only 76 people were convicted, while in the year 2012, 40 people out of 169 registered cases were convicted." 15 Hence, there is an extreme gapbetween the maximum and acquittal, and so a minimum punishment needs to be set upto deter people from committing these child marriages.

4. The police were not empowered to take up Suo-moto cases and thus had to wait till the reporting and investigation of the cases, which allowed the people to easily solemnize a child marriage which will be considered as a valid one.

5. The PCMA also contradicts the Indian Contract Act, $1877,{ }^{16}$ where a child who is minor is not considered capable to give free or a valid consent. But marriages in Muslims are purely contractual as well as the Hindu marriages are also now considered as a combination of both sacramental and contractual. Hence a forced marriage should have been made void and not just voidable.

6. The other grave problem was that the PCMA it does not make any provision which lays down its supremacy over the personal laws, and hence many courts gave primacy to the personal laws and thus upheld the validity of the child marriage. Hence the PCMA needs to expressly state its dominance over the personal laws although the Supreme Court in the case of Independent Thought v. UOI ${ }^{17}$ has clearly stated that "the PCMA being secular law should have primacy over the personal laws."

${ }^{15}$ Press Information Bureau, 'Cases registered under Prohibition of Child Marriage Act, 2006' (MWCD, 11 August 2014), accessed 7 April, 2020.

${ }^{16}$ Section 11, Indian Contract Act, 1872

${ }^{17}$ Independent Thought v. Union of India, 2013, http://supremecourtofindia.nic .in/supremecourt/2013/17790/17790_2013_Judgement_11-Oct-2017.pdf, last accessed- 6 April,2020. 
International Journal of Social Science and Economic Research

ISSN: 2455-8834

Volume:06, Issue:06 "June 2021"

7. Other major drawback in the PCMA is that it does not make the registration of marriages compulsory, which would have otherwise played an important role in securing proof of the ages of the parties and also would have acted as an evidence that marriage has taken place which has also been highlighted by the Supreme Court in the case of Seema v. Ashwini Kumar. ${ }^{18}$

Hence, these were the certain lacunas in the PCMA which acted as loopholes which allowedpeople who committed the offence of child marriage to escape freely. Therefore, if these gaps could be filled by successive amendments then the proper implementation of these laws would be possible and efficiency will be observed.

\section{Discuss in details the various problems faced by the girls who are victims to Child marriages and also discuss the various amendments that can be brought to the existing Act in order to fill the lacunas.}

"The phenomenon of child marriages can be attributed to various reasons. The chief amongst them are poverty, culture, tradition and values based on patriarchal norms". ${ }^{19}$ Some other additional reasons which contributed to the practice of child marriage were the lack of education and knowledge, absence of fear from being punished, dowry, demand for younger brides. Along with them there were other believes owing to patriarchal mindset and sacred religious texts like the Manu Smritis which believed girls to be 'parki thepan', i.e. to be someone's property. Thus, this created a mindset which lead to girls being perceived as a burden on the parents and family and thus gave them a reason as well as an incentive to get ridor to relieve them from this liability as early as possible. The Manu Smritis condemned the male of the house which could be the father or the son for not marrying their daughters or sisters by the time they attained puberty. ${ }^{20}$

Some of the other reason which was given was that the girls were married at an early age to secure them financially and socially and also this was seen as one of the measures conceived by the patriarchal society that by doing so the girl would be protected from the various unwanted attention or masculine harassment in the society and would thus will remain to be chaste, pure and virgin, qualities and values that where considered highly important. Also, at an early age they would not have the complete awareness of the happenings. Hence, at an earlyage they could better adapt to the norms and laws of her family and would listen to her husband as she would be completely dependent on him.

\footnotetext{
${ }^{18}$ Seema v. Ashwini Kumar 2006 (2) SCC 578

19 ibid

${ }^{20}$ ibid
} 


\section{International Journal of Social Science and Economic Research}

ISSN: $2455-8834$

Volume:06, Issue:06 "June 2021"

Hence, we could clearly see the reasons that led to the rampant practice of child marriages in India. But what the patriarchal society failed to see was the unimaginable mental and physical trauma that the children, especially the girls underwent with.

The Child Marriages can be seen as a socio- evil and there are many more reasons to it. These young girls are seen as a burden and thus are made to marry while they are minors or in some cases are even forced to get marry. They are deprived of basic rights that a child should get. They are not expected to study or are not even given an opportunity to get educated or to learn something so as to earn or become capable of earning. Child marriage is thus a grave violationof rights of child as they completely deprive these young girls from not only obtaining proper education but also from living a life of freedom and dignity, something which hampers their social and personal development.

Statistical analyses show more realistic and gruesome picture of the abuse that these girls face in a child marriage. " $57 \%$ of girls in India are married before turning 18 years". ${ }^{21}$ These girls who are victims to child marriage are more open to risk such as sexual harassment and domestic violence. "India has the highest rate of domestic violence with $67 \%$ of faced by women who are married by the age of $18 . " 22$ They are more exposed to early pregnancy leading to more and severe complications such as "hemorrhage, sepsis, eclampsia, obstructed labor and other problems leading to ill health and hence mothers under the age of 15 are five times more likely to die."23 "Thus the maternal mortality among girls aged 15-19 years are about three times higher." 24 "Also the children born out of mothers who are below the age of 18 years have $60 \%$ greater chances of dying in the first year of life." 25 An analyses also showed that the "women aged 15-24 are more prevalent to HIV infections or AIDS."26

Along with thus these girls also face and experience more domestic violence and harassment by the husband and his family. They are denied of equality and also the power in making decisions regarding themselves as well the household.

One more problem faced by the girls who are victims to child marriage where the age of the

\footnotetext{
21 The Hindustan Times daily on 29.08.2006

${ }^{22}$ U.N Children's Fund (UNICEF). Early Marriage: A Harmful Traditional Practice, UNICEF: Florence(2005), p.22

${ }^{23}$ Mensch, Barbara S., Judith Bruce and Margaret S. Greene, The Uncharted Passage: Girls' Adolescence in the Developing World, The Population Council (1998), New York

${ }^{24}$ Barua, A., Heman Apte, Pradeep Kumar, Care and Support of Unmarried Adolescent Girls in Rajasthan,Economic and Political Weekly, Vol XLII No44 November 3-9, 2007, p.54

${ }^{25}$ Ibid

${ }^{26}$ Ibid, pg 26
} 


\section{International Journal of Social Science and Economic Research}

ISSN: $2455-8834$

Volume:06, Issue:06 "June 2021"

husband is much older are at a higher risk to become widows at an early age. These women also suffer discrimination and are also denied property rights and are also abandoned by the in-laws. The more bad aspect of this is that due to lack of education and social skills they have nooptions to earn money are hence become more susceptible to become sex workers to earn money. ${ }^{27}$

Hence, these young girls are deprived right to education, mental and psychological development, and also fundamental rights such as liberty, freedom to speech and expression. Thus, after doing a critical analysis of the Act, the Law Commission in the year 2008 recommended the following changes that should be made to the existing Prohibition of Child Marriage Act, 2006, which were as follows-

1. Also there exists no rationale at keeping the discrepancy in ages. Sexual intercourse is allowed in a marriage if the age of the bride is 15 years. The age at which the girl can give her free consent to sexual intercourse have been given as 16 years in section 375 of the Indian Penal Code and the age of majority as well as the age at which a girl can marry has been defined as above 18 years according to the Indian Majority Act, the Juvenile Justice Act and the Prohibition of Child Marriage Act. Hence this ambiguity should be removed and a uniform age just be adapted.

2. The exception to Section 375 of the Indian Penal Code ${ }^{28}$ should be removed, that is decriminalizing sexual intercourse among couples where the bride is above 15 years and thus to create uniformity as discussed above.

3. All the child marriages below the age of 16 years should be made void and not voidableat the option of the aggrieved party.

4. The time limit to file a petition to annul the marriage should be allowed till the parties to the child marriage attain 20 years of age.

5. The maintenance of the wife according to Section 4 of the PCMA 2006, after the marriage is annulled and until she is remarried must be also made applicable to the cases of void marriages.

6. The provisions of the PCMA 2006 with respect to the child custody (Section 5) and also to the legitimacy to the children (Section 6) in cases where an annulment is taken must

\footnotetext{
${ }^{27}$ Law Commission of India, Report number- 205, Proposal to Amend the Prohibition of child Marriage Act, 2006, February 2008.

${ }^{28}$ Section 375, IPC.
} 
International Journal of Social Science and Economic Research

ISSN: 2455-8834

Volume:06, Issue:06 "June 2021"

continue and should also extend to cases of void marriages.

7. All marriages where the party are between the age of 16-18 should be made voidable at the option of the aggrieved party and all provisions of the PCMA 2006, that is section 4, 5 and 6- dealing with maintenance, child custody and legitimacy of the children respectively should also be made applicable to the voidable marriages.

8. The registration of marriage has been seen as a tool which discourages the child marriage and also helps in generating proof of the marriage in case the husband abandons the women arguing that the marriage was void, voidable or did not take place. Hence registration of marriages should also become compulsory within a given period of time by the government.

9. To resolve the disparity and discrimination that exists for setting different ages of marriages should also be made uniform and should be made 18 years for both.

10. The PCMA 2006 should be given supremacy over all other personal laws and any law which contradicts the PCMA, 2006 should be amended. ${ }^{29}$

\section{CONCLUSION}

After researching about the topic carefully, the researcher agrees with the Law Commission Report (Report No. 205) given in the year 2008 after critically analysing the Prohibition of the Child Marriage Act, 2006.

Although the Central Government took a positive step forward in revoking the Child Restrain Act, 1929 and replacing it with the PCMA, 2006, yet the researcher thinks that the law makershad addressed only half of the issues which were present in the 1929 Act. This resulted in creation of gaps or lacunas in the new act of 2006, and thus does not efficiently resolves the problem of child marriages.

The researcher thinks that the reason for the failure can be the patriarchal mindset of the draftersor even the exclusion of women, their experiences and voices and opinions can be one of the other reasons. Hence, the lack of women participation can also be the biggest reason which has led to the inefficient drafting of the laws, due to which even after implementation it has failed to curb the evil practice of child marriages.

${ }^{29}$ Law Commission of India, Report number- 205, Proposal to Amend the Prohibition of child Marriage Act, 2006, February 2008. 
International Journal of Social Science and Economic Research

ISSN: 2455-8834

Volume:06, Issue:06 "June 2021"

The other lacunas given in the paper are many, but what the researcher feels is that there are still many aspects that the Law Commission has either not mentioned or has not given a proper suggestion to amend them. Some of these are-

The law commission recommended to fight the discrimination of age issue by making the age for both boys and girls to 18years, which the researcher feels is unreasonable. This is because what we wanted to fight was the denial of education and other learning opportunities to these girls, but by making such amendment although the discrimination will be resolved, but then both boys as well as girls will be denied of the educational opportunity, or the aspect could beit will create no change because of the loose end.

Secondly the researcher feels that increasing the time limit for filing a petition to get the marriage annulled is other topic which neither the PCMA nor the Law Commission suggested. Hence the researcher feels the time bar of 2 years should be removed as the parties who are victims of child marriage will still be not mature as the girl will only be eligible to file a petitiontill, she is 20 years whereas the boys can file till 23 years of age. This is a clear violation of equality guaranteed under the Constitution as well as is also unreasonable as these girls are still small, immature and dependent, hence are not competent enough to take decisions for themselves.

The IPC should also be amended and the age of giving consent for the sexual intercourse shouldbe made 18 years, as well as the exception for section 375, that is decriminalization of maritalrape if the girl is above 15 years should also be removed.

\section{ACKNOWLEGEMENT}

This research paper is a result of sincere efforts put by the researcher. This work would not have been possible without the support and help of many people.

First and foremost, I would like to extend my heartful gratitude to Ms. Mita Manoj Kumar, for her help and guidance, without which the work would not have been possible. I would also like to thank her for her constant supervision. Lastly, I would like to thank her for giving me this opportunity to make a project on this topic, which has given me a chance to increase my knowledge about the topic.

\section{BIBLIOGRAPHY}

\section{ACTS REFFERED-}

1) The Child Marriage Restrain Act, 1929. 
International Journal of Social Science and Economic Research

ISSN: 2455-8834

Volume:06, Issue:06 "June 2021"

2) The Prohibition of Child Marriage Act, 2006

3) The Indian Penal Code, 1860

4) The Indian Contract Act, 1872

\section{BOOKS REFFERED-}

1) Family Law Lectures, by K. Kusum and Poonam Pradhan.

2) Family Law in India, by Prof. G.C.V. Subba Rao

\section{CASES REFFRED-}

1) Mt. Jalsi Kaur vs. Emperor AIR 1933 Patna 471

2) Ram Baran vs. Sital Pathak AIR 1939 All 34

3) Birupakshya Das vs. Kunju Behari AIR 1961 Orissa 104

4) Sivanandy vs. Bhagavathyamma AIR $1962 \operatorname{Mad} 400$

5) Panchireddi Appala Suramma vs. Gadela Ganapatlu AIR 1975 AP 193

6) Vankataramana vs. State AIR 1977 AP 193

7) Independent Thought v. Union of India, AIR 201710 SCC 800

8) Seema v. Ashwini Kumar 2006 (2) SCC 578

\section{ARTICLES-}

1) The Prohibition of Child Marriage Act, 2006: A Critical Analyses, https://shodhganga.inflibnet.ac.in/

2) Law Commission of India, Report number- 205, Proposal to Amend the Prohibition of child Marriage Act, 2006, February 2008

3) Child marriage under Hindu Personal law: factum valet or an issue for protection of Human rights of women, vol. 1, ILI Law Review by Dr. Vandana. 
International Journal of Social Science and Economic Research

ISSN: 2455-8834

Volume:06, Issue:06 "June 2021"

4) Eliminating Child Marriage in India: A Backdoor Approach to Alleviating Human Rights Violations, Vol. 26, Boston College Third World Law Journal by JacquelineMercier 